\title{
A Trip to the Past and Future of Educational Computing: Understanding Its Evolution
}

\author{
Sinem Aslan \\ Charles M. Reigeluth \\ Indiana University, United States
}

\begin{abstract}
Although machine use in education was introduced in the 1920s with instructional radio and 1950s with instructional television, these technologies lacked one of the most important components of learning - interaction. Computers have filled this void. The functions they have served, the ways they have been used, and the terms they have been given have changed since their introduction to our schools, but their rooted presence in our educational lives has continually increased over time. Our in-depth review of the literature illustrated that there are three distinct periods of educational computing based on the predominant computer technologies and computer functions of the time. We named these three periods the "Mainframe Period", "Microcomputer Period", and "Internet Period". Taking the past and current trends into account and considering such shifts in society as moving from standardization to customization and personalization, from proprietary resources to open resources and from using different tools for different functions to convergence of functionalities in one tool, we propose the next period, which we call the "Personalized Computing Period", in which the predominant computer technology will be "Personalized Integrated Educational Systems" that serve four major functions to support the informationage paradigm of education: Record-keeping, planning, instruction, and assessment, as well as such secondary functions as communication, general student data, school personnel information and system administration.
\end{abstract}

Keywords: History of educational computing; Information-age paradigm; Personalized Integrated Educational System; Social networking

\section{Introduction}

Since the introduction of computer technologies, people have been trying to computerize tasks in order to spend less effort and get more output (Cuban, 1986). The huge effect of computer technologies can be seen in almost every area of our lives, such as industry, health care, military, transportation, and communication. We can add tens of other areas to this list to show how extensive the effects of computers are. Taking health-care as a starting point, it is impossible not to be surprised at how easily computerized systems can calculate and picture the diameter of a single heart vessel, which can save someone's life (American Heart Association, 2009). Computers' contributions to communication systems have been "shortening distances" all over the world and building virtual bridges for creating and maintaining relationships. A decade ago, it was difficult to 
imagine that we would be able to sit in front of our computers and easily video-conference at no cost with people living thousands of miles away.

This paper focuses on computers as learning and teaching tools in education. As pointed out by Schofield (1995), computer use is influenced by the context of the learning setting, and computers also affect the context in turn. Computers have increasingly been affecting education, and it seems that they will likely to shape the future of education. To understand these effects, it is helpful to take a trip to the past - specifically to the time when computer systems were first introduced into our education systems. Literature shows that the roles of computers in education have evolved a lot since that introduction.

There are many dimensions on which technology use in education has changed. For instance, Taylor and Chonack (1982) saw three different roles for computer use in education: As a tutor, a tool, and a tutee. However, they mentioned that it is possible to add more roles to this framework because of ongoing advancements in technology. In addition, Venezky and Osin (1991) identified a number of different stages of computer-assisted instruction: Age of Engineers, Acronym Age, Age of Titans, and the Age of Small Wonders. In this review of the literature, we group the stages and ages into three major periods based on the primary technology that leads each period. These periods are: 1) MainframePeriod, 2) Microcomputer Period, and 3) Internet Period.

Understanding these three periods sheds light for predicting possible future trends in computer use in education. Furthermore, according to many experts (e.g., Banathy, 1991; DarlingHammond, 1990; Duffy, Rogerson, \& Blick, 2000; Fullan, 1993; 2003; Reigeluth, 1994; Toffler, 1980), educators recognize that educational needs are not the same now as in the past, and they concluded that our education systems need systemic transformation (paradigm change). Therefore, we will use computer-use trends in the previous periods, along with educational trends in systemic transformation, to foresee a fourth, information-age period, which will focus on customization and Open Educational Resources, and we will identify Personalized Learning Systems as the leading technology of this period, which we call the "Personalized Computing Period".

As Merrill, Hammons, Vincent, Reynolds, Christensen and Tolman (1996) suggested, before reaching the current state of computer technology in education, there were some evolutionary steps. This article's ultimate goal is not just to describe the history of this evolution, but also to analyze the changing ways in which computers have been used in education. This analysis will be helpful for guiding the direction of future investments for computer use in education and assessing the merits of these investments.

It is important to emphasize that our framework of four major periods in educational computing is a general model of the evolution of educational computing over time. Within each period, we discuss predominant uses of technology in education. However, there is an obvious distinction between significant developments and significant implementations of technology in education. Many promising developments have never been widely implemented. Furthermore, greater availability of technology tools does not necessarily mean more technology use in classrooms. Schools opened their doors to computer technology in the 1950s, but technology has yet to enter many classrooms because there are so many barriers, including lack of resources. Our literature 
review focuses on uses of computers that actually penetrated the education market (unlike intelligent tutoring systems).

\section{Periods of Computer Use in Education to the Present}

\section{Mainframe Period (Late 1950s to Late 1970s)}

In the 1920s, use of instructional radio laid the foundations of machine-use in educational settings. With the introduction of instructional television in the 1950s, educational technology started to be considered as a promising field to make classrooms engrossing and generative places for learning (Cuban, 1986). In addition to being amazing innovations, radio and television were used in education to meet some essential needs. As pointed out by Cuban (1986), a shortage of teachers played an important role in the need for educational technology in classrooms at that time. Moreover, there were some financial considerations, such as being able to hire fewer teachers, and some strategically important reasons, such as allowing less prepared teachers in the schools. At the beginning, there were too many expectations for radio and television. After a while, these were considered to not respond well to the actual needs and goals of education.

Frick (1991) discussed the impact of television on education and its role of communicating messages worldwide using images and sound. He identified some missing sensory components, such as smell, taste, and touch. On one hand, as pointed out by Frick, television had an important impact on education. On the other hand, some research revealed that there was not much difference between conventional classes and classes with instructional television and radio (Cuban, 1986). These results were not surprising, since an important method for learning was missing in these two educational technologies. That method was interaction, which is considered a powerful tool for learning (Garrison \& Cleveland-Innes, 2005). Merrill et al. (1996) underlined this method's importance for student learning, yet there was only one-way communication between each of these two technologies and the students. Computers met the need for a technology that could provide an interactive environment in the classroom. They opened a new age in the history of education and affected the way students learn. As Tyack and Cuban (1995) pointed out, these small machines had much more important impacts on education than any other machine to that time.

Beginning about 1958, the earliest applications of computers emerged as programs for teaching certain subjects. IBM's Teaching Machines Project is considered to be the pioneer implementation of this application. Initially, the IBM 650 computer was used for simulating a teaching machine, based on Skinner's (1954) programmed instruction, for teaching basics of binary arithmetic (Venezky \& Osin, 1991). Taylor and Chonacky (1982) saw this function of the computer as tutor, since computers were in the role of teaching a certain subject. There was a great effort to develop various educational programs working on these machines. Venezky and Osin (1991, p. 32) used the term "Age of Engineers" (late 1950s and early 1960s) to illustrate that there was a period of computer-assisted instruction in which the computer provided a mechanical implementation of instruction. 
Although LOGO was a later implementation of computer programming, we find it helpful to mention in this section, since it was considered an important pioneer of programming tools in education. In 1967, Seymour Papert and his colleagues developed the first version of LOGO in the MIT Artificial Intelligence Laboratory (Logo Foundation, 2000). LOGO was a simplified programming language that enabled children to use various commands to "teach" a turtle to draw objects on the screen that could be printed to a piece of paper (Jonassen, 1996). Throughout the 1970s, research was conducted to evaluate the effectiveness of LOGO for teaching programming skills in schools, including the Brookline Public Schools near Boston (Logo Foundation, 2000). However, Beaver (1989) pointed out that in those schools, students spent only $14 \%$ of computer access time on computer programming, while they spent $84 \%$ of their time on computer-assisted instruction and other computer applications (as cited in Jonassen, 1996). This illustrates that computer programming was not a predominant application of computers in education at that time. As described by Jonassen (1996), the reason behind this is that to learn programming, even a simple language such as LOGO, takes a lot of time, and the learning gains from programming may not justify the amount of time spent learning that language. Furthermore, what LOGO taught was not a central part of the curriculum at that time.

Following the "Age of Engineers", Venezky and Osin (1991, p. 35) identified another age called the "Acronym Age" of CAI (middle 1960s). In this age, government- and military-funded projects took place, such as SOCRATES (System for Organizing Content to Review and Teach Educational Subjects) and CLASS (Computer-based Laboratory for Automation of School Systems). CLASS (Silberman, 1962) was basically a drill system, and SOCRATES (Stolurow, 1966) was a computerbased tutorial system. This age was followed by the "Age of Titans" (late 1960s through the late 1970s) (Venezky \& Osin, 1991, p. 39), in which the most well known projects received extensive funding and public interest. There were a lot of research studies and critical evaluations on them. Two of the most important applications of this age were PLATO and TICCIT.

In 1959, an individualized instruction system called PLATO was developed by a number of scientists in the University of Illinois. PLATO was a computer-assisted instruction tool in mainframe computers. There was a single central computer and independent computer terminals for the students. Each of these terminals could interact with the central computer using a touch-sensitive screen and a keyboard. This system supported graphics, which were ideal for simulations. It also supported drill and practice, tutorials, and problem solving. All these functions refer to the use of computers as tutors in the view of Taylor and Chonacky (1982). The logic behind this system was simultaneous individualized delivery of computer-managed instruction (Rahmlow et al., 1980). Due to the expense of a mainframe system, in 1980 micro-PLATO was developed for use on microcomputers (Merrill et al., 1996).

The popularity of computer-assisted instruction continued with the development of TICCIT (Timeshared, Interactive, Computer-Controlled Information Television) around 1975. TICCIT was developed as a mini-computer system (Merrill et al., 1996), combining computer and color television technology. Merrill et al. (1980) emphasized some major differences between this computer-based instructional system and the previous ones. One of the most important differences was its ability to support learner control. Also, authors were responsible for providing the content to be taught, but the instructional strategy was built into the system in the form of standard strategy components. The students could choose the strategy components, which 
contributed to the learner control function. For instance, students made the decisions as to when to start another topic, to return to a previous topic, and to view the rule, some examples, or some practice for the current topic. In the perspective of Taylor and Chonacky (1982), in this system computers were used as tutors. However, TICCIT was on a level of sophistication well beyond just drill and practice.

In this Mainframe period of use, computer-assisted instruction gained much popularity, and attempts were made by many different organizations to produce more efficient and effective systems. MECC (The Minnesota Educational Computing Corporation) was founded in 1973 to support mainframe computer time-sharing services in Minnesota schools. After a while, MECC designed the first software membership program to obtain high quality software at cheap prices. Similarly, WICAT (World Institute for Computer Assisted Teaching) was formed in 1977 to develop software for English, mathematics, and reading. CONDUIT was another consortium that was begun in 1971 to improve the quality of CAl courseware (Merrill et al., 1996). All of these efforts were made to apply computer technologies in educational settings, almost exclusively in the role of computer as tutor.

However, there is an important point that pervasive availability does not mean pervasive use (Bichelmeyer \& Molenda, 2006). In 1982, the Office of Technology Assessment released a report revealing that technology had started to assume an important promising role in education (as cited in Venezky \& Osin, 1991). The word "started" is a key word in this conclusion, since it reflects the adoption level of technology in the schools. In addition to this report, Tyack and Cuban (1995) reached a similar conclusion concerning the use of computers among students. They revealed that students spent only about an hour a week using computers in the schools. More importantly, the purpose of use varied significantly. For instance, low-income students usually used drill and practice on computers, rather than problem solving and complex thinking (Tyack \& Cuban, 1995).

To sum up, for the first stop on our journey, we went back to the 1950 s and also looked at different educational technologies that led up to the period. Computers were first used as teaching machines. In this Mainframe period of use, they were used as both tutees and tutors. In later years of this period, some heavily funded projects utilized computers as tutors through drills and tutorials. Many organizations tried to make computers pervasive in K-12 education, but they could not penetrate as pervasively as desired in this period, even though modest positive effects of CAI were found in all grades of formal education (Kulik et al., 1985, as cited in Saettler, 1990). Instead, as pointed out by Alessi and Trollip (1985), up to the mid 1970s, the educational use of computers was more common in universities, corporate settings, and the military than in K-12 education.

\section{Microcomputer Period (Late 1970s - End of 1990s)}

With the introduction of cheap desktop computers, these machines were placed at the top of the list of educational fads (Cuban, 1986). In the early 1970s, microcomputers were introduced in kit form. Soon after that, pre-assembled computers such as the Commodore Pet, Apple, and TRS-80 took their places in educational settings (Merrill et al., 1996). Venezky and Osin (1991, p. 46) called this period "The Age of Small Wonders" (the late 1970s through the late 1980s), referring to 
microcomputers as small wonders. After this introduction, workshops were offered to teachers to learn how to program computers and to use these machines in classrooms. Parents raised money to buy computers for their children's schools (Cuban, 1986), which shows the perception and attitude of parents toward these innovations at that time. Tyack and Cuban (1995) explained the possible reasons behind this positive attitude: Families believed that if their children were not familiar with these machines, they would have less chance to find a job in the future since they saw that computers were being integrated widely into the workplace.

According to Molnar (1997), the 1980s were a period of rapid growth of computer-based education. One of the possible reasons for this rapid growth was the availability of more powerful microcomputers at lower cost. Apple II microcomputers gained much popularity, and they were used widely in the schools. In 1981, when the IBM Personal Computer was released, there was an increase in demand for microcomputers in business and industry. However, due to having an early lead, reasonable cost, courseware availability, better graphics capability, and some other advantages, Apple II dominated educational settings. In contrast, the IBM PC started to be widely used in higher education and corporate settings.

In 1983, Apple introduced the "Schoolbus Network" (Cuban, 1986, p. 87) to the market, which enabled teachers to communicate with their students via a computer network. A teacher's station and students' computers were connected to each other so that the teacher could view students' work, exchange messages, and give feedback. This network application was revolutionary because it altered the traditional ways of instruction and classroom management. Unfortunately, it was only used in a few schools.

In 1984, Apple's Macintosh computer was released, which changed the field of micro-computing a lot because of its unique feature of mouse input and better graphical and text support. This computer came with a free HyperCard program allowing teachers to make their own software applications and tutorials for students. However, the Macintosh's higher cost and poor availability of courseware prevented it from penetrating the educational setting much (Alessi \& Trollip, 1991). Still, the increasing availability of microcomputers resulted in a dramatic increase in technology use in schools. The US Congress - Office of Technology Assessment (1988) revealed that the proportion of US schools that had one or more computers rose from 18\% to 95\% between 1981 and 1987. Moreover, as stated by Schofield (1995), the average number of computers in schools increased about tenfold between 1981 and 1985. Research shows that in 1985, at least one computer was available for instruction in 92 percent of all secondary schools and 82 percent of all elementary schools (Cuban, 1986).

In the Mainframe period of educational computing, computer literacy had been a problem because stakeholders were not familiar with these new machines. Therefore, it was difficult to expect an effective utilization of them in classrooms in that period. However, in the Microcomputer period, computer literacy became less of an obstacle, since the availability and use of computers had increased. Strikingly, students became much more knowledgeable than their parents and even in some cases than their teachers in this period of use (Golden, 1985). In 1982, Time headlined, "Here Come the Microkids" (as cited in Cuban, 1986, p. 72), referring to students as microkids to illustrate how erudite they were about computers. 
Rapid advancements in computing technology continued to take place after 1987. In 1989, the NeXT computer was introduced. It was considered the latest version of microcomputers providing better speed, storage, multi-tasking, graphical capabilities, and so forth. However, it was an expensive computer like Apple's Macintosh. Therefore, it could not be used widely in educational settings (Alessi \& Trollip, 1991). Expense was one of the barriers preventing the acceleration of educational computing. Another barrier was resistance of stakeholders to using educational technology. According to Archbald and Porter (1994), throughout the 1980s, schools were resistant to any change, especially top-down change. Similarly, Cuban (1986) stated that in the 1980s, teachers were often blamed for closing the doors of their classrooms to these new innovations. Still, this resistance could not stop computers from becoming increasingly ubiquitous in schools and classrooms.

In this Microcomputer period, several projects and programs were designed to facilitate computer use in the schools. The IBM Secondary School Computer Education Program and Apple Classroom of Tomorrow were two of the most important projects during these years (Alessi \& Trollip, 1991). Students in the selected schools were provided computers to assess their effectiveness. However, several problems were ignored in these projects. Alessi and Trollip identified one as teachers not knowing how to utilize computers in their classrooms. This was a severe problem, since teachers were given almost total responsibility for technology use in their instruction, rather than giving paraprofessionals much of the responsibility. Having new technologies and knowing about them are not enough to use them effectively in educational settings. Instead, as Jonassen (1996) pointed out, it is important to know how to utilize these tools appropriately in learning contexts. When appropriate training was provided, there were many successful and vital implementations of computers in this period of use. As Golden (1985) stated, since computers could be operated by just touching a button, they were very effective for disabled students. Similarly, Golden, Schmidt, Weinstein, Niemic and Walberg (1986) stated that educational technology - particularly computers - can be used as means for increasing the academic success of students with disabilities. In the 1980s there were serious attempts to make use of computers in special education (Woodward \& Reith, 1997).

Drill and practice was a common type of computer use in the 1980s. In these applications, computers presented a stimulus, such as an addition problem, to the students to enter the correct response. The computer was designed to then give feedback through text or some kind of eyecatching graphics. Therefore, drill and practice applications were typically not used for teaching new content, but instead for retaining and reinforcing previously presented content (Morrison, Lowther, \& DeMeulle, 1999). Tutorials, however, were used for both presenting new content and reinforcing previous content. Jonassen (1996) described that, in the 1980s, tutorial use was common in education. The unique feature of tutorials, which are distinguished from drill and practice applications, is that individual differences were taken into account. Moreover, tutorials could provide remedial instruction when learners gave a wrong response.

Another less common use of technology in education during the Microcomputer period was "Intelligent Tutoring Systems" (Jonassen, 1996, p. 6). Intelligent Tutoring Systems (ITSs) were developed in the 1980s and 1990s by researchers working on Artificial Intelligence to teach procedural knowledge and problem solving skills. ITSs were sometimes called intelligent CAI. There were many criticisms of these systems. Jonassen (1996) emphasized that giving simple textual 
feedback in ITSs cannot replace sensitive feedback by a human tutor. Moreover, these systems were generally implemented in universities, and there was not a significant implementation in the public schools.

In the early1990s, many other applications of computers in education appeared. Word processing applications were a predominant form of computer use among students in this period because students could finish their work more easily than using pen and paper, and they could change the text easily (Morrison et al., 1999). Another application was the electronic spreadsheet. Educators recognized the value of spreadsheets as being strong instructional tools beyond their numbercrunching value. Therefore, students started to manipulate and analyze data in spreadsheets (Morrison et al., 1999).

Database management systems also became popular in the Microcomputer period. Morrison and colleagues described that teachers were using database applications for lesson objectives focused on critical thinking skills. With the help of database management systems, students could store, organize and manipulate data for their classes. Jonassen, Peck and Wilson (1999) illustrated that one way of using database management systems was to use them as "study guides" (p. 159). Students were expected to analyze short stories and fill in the database worksheets with their findings. Drawing tools were another popular application of computers in education. After research showed the value of visualization in instruction, these tools gained even more popularity. Morrison and colleagues (1999) described a successful use of drawing tools as teaching students to draw what they observe. This helped students to visualize and retain their understanding of new material.

To summarize, after our trip to the Mainframe period, we traveled to the Microcomputer period. With the introduction of cheap microcomputers, availability problems declined, and these machines gained popularity among parents, teachers, students, and administrators. Several versions of microcomputers were introduced with different capabilities. Moreover, there were many projects to advance technology use in classrooms. With these advancements, computer literacy among stakeholders became common, with computers' being a part of their daily lives. Drill and practice applications and tutorials gained popularity and became educational fads. ITSs were developed but were not successful in penetrating $\mathrm{K}-12$ or even higher education. Word processing, spreadsheets, database management systems, and drawing tools became popular examples of computer "tool" use in education in the Microcomputer period. In short, starting from the late 1970s and extending to the end of the 1990s, computers became commonly used as tools for enhancing instruction.

\section{Internet Period (Early 2000s - Today)}

In this period, the increasing availability of technology in public schools was remarkable. In 1991 (the mid Microcomputer period), the availability of microcomputers was one for every 18 students in the schools, and in 2000 (the early Internet period) there was one for every five students (Christensen, Johnston, \& Horn, 2008). More importantly, with the introduction of the World Wide Web, another need emerged in the schools - an Internet connection. Although the origins of the Internet date back to the early 1960s, it took a while to mature and penetrate into educational 
settings. According to Wells and Lewis (2006), the percentage of schools having an instructional room with Internet access increased from 3\% in 1994 to 94\% in 2005.

Bichelmeyer and Molenda (2006) stated that there was extensive availability of Internet connections in schools in 2006. They reported that teachers used web sites during their instruction as secondary resources, while textbooks were used as primary resources. However, there was a change in focus from using computers mainly for teaching and learning to using them more for assessment, driven by the No Child Left Behind (NCLB) initiative. Christensen et al. (2008) and Bichelmeyer and Molenda (2006) did not see delivery of instruction as the primary role of technology in this period. In addition, Bichelmeyer and Molenda (2006) reported that "professional development" and "data management" were the two top priorities of the states for educational technologies. "Internet connectivity" (p. 60) ranked third in these state priorities.

Jonassen et al. (1999) pointed out some effects of the Internet on education. There was an explosion of access to content on the Internet. Teachers and textbooks no longer had a monopoly on content, and this allowed a change in the teacher's role. Jonassen and colleagues(1999) proposed that Internet learning activities provide an explorative learning environment in which learning depends on exploring the knowledge to be learned in a way that they can construct meaning. The explorative learning approach can be seen as a branch of constructivism, which is considered an umbrella term for various views in education (Duffy \& Cunningham, 1996) and which is a commonly embraced term in the educational community (Sharma, Xie, Hsieh, Hsieh, \& Yoo, 2008). There is a strong relationship between constructivism and Internet-based activities. Sharma and colleagues (2008) stated that the invention of personal computers and the Internet caused great interest in constructivist learning environments. Pea (2000) reported the results of a study which found that the more constructivist the teachers, the more they used Internet-based activities in the classroom.

With the advent of wireless technology, schools found it easier and less expensive to adopt this emerging technology. Bichelmeyer and Molenda (2006) reported that laptops with wireless technology demonstrated a remarkable growth during 2005. Fifty-four percent of K-12 schools had mobile computers available for students during 2004. Roschelle (2003) extended the term "laptops" to handheld devices, including Palms, and highlighted the success of the "graphing calculator" (p. 2), which made multiple representations available such as graphs and equations for high school mathematics classrooms all over the US. Such uses of handheld devices became more popular in 2006, and the "Clicker" is one of the most popular examples (Bichelmeyer \& Molenda, 2006). With the growing use of technology for assessment, this multiple-choice quiz system became popular in classrooms.

As opposed to some beliefs stating that use of Internet results in isolation and loneliness of its users, Amichai-Hamburger and Hayat (2011) reported that use of the Internet can actually facilitates social interactions among its users. In support of such interactions, Collaborative Digital Tools (Brown \& Green, 2008) became important emerging technologies in K-12 education. One of the earliest tools for collaboration was called "CSILE" (Scardamalia, Bereiter \& Lamon, 1994). It stands for Computer Supported Intentional Learning Environments. In an R\&D project, there were eight networked computers connected to a file server having a communal database. The database had text and graphical notes, which were developed by students. Anyone could add new notes 
and attach new graphics. The aim of this project was to foster "collective construction of public knowledge" (p.211). Several studies assessed the effectiveness of this project. Scardamalia and colleagues (1994) reported that they observed advantages for CSILE students in terms of "understanding, metacognition and active construction of knowledge" (p.222). More recent collaborative digital tools include weblogs, wikis (Godwin-Jones, 2003), and instant messaging. As the evaluations of the CSILE project show, these tools have some promising value in today's K-12 education.

Singh and Dika (2003) emphasized the importance of social networks and reported a significant improvement in educational outcomes resulting from academic and emotional support given by network members. As a form of social networks, weblogs (blogs) have become one of the more common ways of using technology in education in this Internet period. Blogs provide a web-based communication environment in which a group of people shares their interest about a specific topic (Charnitski \& Harvey, 2007). Huffaker (2005) stated that blogs are important tools to support selfexpression and creativity since they look like a personal diary. Wikis are examples of Web 2.0 technologies that enable information sharing, interoperability, user-centered design, and collaboration (Wikipedia, 2009). Wikis reduce the need for technical literacy to a minimum (Ebersbach, Glaser, \& Heigl, 2005), which increases the variety of users from students to teachers in K-12 education. The power of being accessible to anyone, independent of time and place, is an important feature of wiki pages.

Brown and Green (2008) pointed out that another emerging technology is "Personal Broadcasting" (p. 11). This technology is used for distributing sound or video files to users. Brown and Green (2008) observed a great surge of this technology in K-12 education. One of the most famous applications of personal broadcasting is podcasting. The authors pointed out that with podcasts, students can share their media and have access to media created by other students. Podcasting has been growing at a rapid pace since it was introduced in late 2004 (Brown \& Green, 2007). Its increasing popularity among teachers and students seems likely to continue into the future (Brown \& Green, 2008).

Data Management Systems (Brown \& Green, 2007) and Course Management Systems (CMS) (Simonson, 2007) are other up-and-coming technologies in this period of use. Because of the trend to use technology for collecting and managing student assessment data, in this period Data Management Systems have received great consideration and application in K-12 settings. Also, as Simonson (2007) points out, CMSs are "software systems designed to assist in the management of educational courses for students, especially by helping teachers and learners with course administration" (p. 7). They have gained great popularity in higher education, and their use is spreading to $\mathrm{K}-12$ education.

In today's K-12 settings, the predominant use of a CMS such as Moodle entails content and data management such as keeping records on students and storing course material as well as offering a way of delivering instruction. Similar to this observation, Brown and Green (2008) pointed out that in this period, the use of computer technology in K-12 education has been highly focused on administrative issues such as attendance, grading, and communications with stakeholders. 
Although a number of promising technologies were identified above, there are some barriers that hinder the effective penetration of those technologies into education. Bichelmeyer and Molenda (2006) reported the following barriers to technology use in classrooms: Lack of quality professional development, having too few computers in the classroom, and lack of time to plan for computer use. Earle (2002) added resistance, passivity, school cultures, traditions of teaching, vision, and leadership to these barriers. There are several technological tools that teachers can use for their instruction. However, they need extra training to learn how to use them. Unless teachers get enough training, they may use instructional technology tools ineffectively or they may decline to use them since it would take too much time to get familiar with them. Speed and ease of use are two important factors affecting teachers' use of tools for instruction. Therefore, policymakers should take these factors into account.

To sum up, in our journey to the Internet period, we have seen that the Internet has shaped the use of technology in K-12 schools. The increasing availability of the Internet in this period of use has affected the way stakeholders use technology in the schools. It is strikingly obvious that an important use of technology has been for administrative issues such as grading and recordkeeping. The Internet has been helpful for these functions of the computer because of the need for communication. However, since most of the technologies - including wireless, portable computers, Web 2.0 technologies, and Personal Broadcasting - are relatively new technologies, their use in education is just beginning. However, they are likely to play an important role in the future since they all can facilitate personalization and customization of learning.

Table 1 summarizes the major ways that educational technology has been evolving in terms of different configurations of computers and their different functions during the three periods.

Table 1. Periods, Predominant Computer Technology, and Functions

\begin{tabular}{|c|c|c|}
\hline Period & Computer Technology & Functions \\
\hline Mainframe & Mainframe computers & Programming \\
\hline \multirow[t]{3}{*}{ period } & Minicomputers & Computer-assisted instruction \\
\hline & & Basic drill \& practice and tutorials \\
\hline & & Computer-managed instruction \\
\hline \multirow{5}{*}{$\begin{array}{l}\text { Microcomputer } \\
\text { period }\end{array}$} & Microcomputers & Advanced drill \& practice and tutorials \\
\hline & Personal computers & $\begin{array}{l}\text { Intelligent tutoring systems } \\
\text { (Uncommon) }\end{array}$ \\
\hline & & Spreadsheets \\
\hline & & Database management systems \\
\hline & & Drawing tools \\
\hline \multirow{4}{*}{$\begin{array}{l}\text { Internet } \\
\text { period }\end{array}$} & Networked-personal computers, & Collaborative digital tools \\
\hline & Portable computers (laptops and & Personal broadcasting \\
\hline & handhelds), & Learning management systems \\
\hline & & Data management systems \\
\hline
\end{tabular}




\section{The Future of Educational Computing}

Our journey through the history of educational computing started in the 1950s, along with a brief look at other educational technologies that led up to the period, and has taken us up to the present. In short, we have observed the past and current uses of educational technologies. Based on these observations and trends across the periods, in this section a future period, the "Personalized Computing Period," will be proposed and discussed.

\section{Personalized Computing Period}

Pea (2000), Christensen et al. (2008), and Brown and Green (2008) reported that, despite high investments in educational technology, its use in the schools is very limited, and the effectiveness of the current level of integration is an important concern. Christensen et al. (2008) state that fifth graders spend only about 24 minutes a week on computers, and eighth graders use computers for 38 minutes a week in class and in computer labs. The authors conclude that computers are being used infrequently and as merely tools or a topic to be taught in the schools. More importantly, these uses are only to support the current teacher-centered, one-size-fits-all paradigm of education (Cuban, 2001). In other words, teachers are still the "sage on the stage" and deliver the instruction. They use computers as a minor supplement to enhance their teaching.

This type of teacher-centered instruction is a practice of the industrial-age paradigm of education; however, the shift from the industrial age to the information age has happened. The needs of students, teachers, and education itself have changed due to this shift. Now, students are "digital natives" (Prensky, 2001, p. 1), since they were born in a digital society. They started using several technologies at an early age - including handheld devices, cellular phones, and laptops - and their brains have become wired differently from those of previous generations. Teachers tend to be "digital immigrants" (Prensky, 2001, p. 2) who struggle to adopt new technologies that can better serve their students. Consequently, there is a great need for technologies that can better meet students' needs. Before identifying features of such technologies, it is wise to look at trends in today's society, which might help to better understand the needs of students and teachers today.

First, there is a trend from standardization to customization and personalization in the information age. This trend can be best observed in emerging web technologies. Web 1.0 was introduced for spreading and sharing information. Then, collaboration and interaction components were added, creating Web 2.0. Now, Web 3.0 technologies have been introduced that have customized and personalized applications such as igoogle.

In addition, there is a trend from time-based student progress to attainment-based progress in schools. Instead of keeping time constant, which forces achievement to vary (since students learn at different rates), time should vary by allowing each student the amount of time he or she needs to master a standard (Reigeluth, 1995). Mott and Wiley (2009) use the term "Artificial Time Constraints" to refer to the industrial-age practice of time-based progress. In contrast, attainmentbased progress allows students to move on as soon as - and not before - they have each mastered 
a standard. This can accommodate different needs and paces of learning for each of the individual students, which also allows customization of learning.

Moreover, we observe a major trend in educational resources. From being proprietary, educational resources are turning to being open resources so that they are available without costing hundreds of dollars. To illustrate, Google, a leading web-application company, offers many open resources that educators and students can take advantage of. For instance, in order to create a classroom website, a teacher does not need to have programming or web-development skills. Using Google Sites, it is very easy to create a website and customize the content of the website based on the needs of teachers and students.

Another technology trend, convergence of functionalities, can also be observed in today's society. To illustrate, Apple, a leading technology company, first introduced iPods for listening to music. Then, Apple released a number of different variations of iPods by adding different functionalities including watching videos. Although iPods were first introduced for listening to music, the latest version has features for listening to the music, watching movies, playing games, running different applications, and browsing the Internet. Apple also released the iPhone and the iPad, which have all the iPod Touch features plus the 3G networking feature. Instead of having three different devices, one device can accomplish all of the functionalities, which is more efficient.

An educational technology should also keep up with these trends in society in order to be adopted and utilized effectively in the schools. In this sense, an educational technology should be available mostly for free, have an online infrastructure for ease of access, support attainment-based student progress, provide an open-source environment that is customizable, have built-in personalization tools such as Web 3.0 applications, and offer a number of different functionalities in order to meet the needs of students and teachers in the information-age paradigm of education. Toward this end, we see great potential for a new kind of Learning Management System some call a Personalized Integrated Educational System (PIES) to facilitate learning.

PIES is envisioned as open-source, integrated, online environments designed for teachers, students, administrators, and parents in order to enhance teaching and learning by providing many built-in functions. In PIES the emphasis is on integrating and using technology for student learning, which was indicated by Ross, Morrison and Lowther (2010) as one of the aspects of the future of educational technology. These systems will be designed and developed to support four major functions of information-age educational computing (Reigeluth, Watson, Watson, Dutta, Chen, \& Powell, 2008): Record keeping for student learning, planning for student learning, instruction for student learning, and assessment for/of student learning. Current report cards will be supplanted by the record-keeping function, which will provide information about what is available to learn (required and optional standards), what each student has already learned, and each student's characteristics that influence learning. Based on the data inthe record-keeping function, the planning function will act as a tool to design and develop a personal learning plan for each student, based on their individual goals and current attainments. Students will choose projects to achieve their current learning goals. The instruction function will support students' learning by facilitating projects, managing a personalized"instructional space" related to each project, and assisting in developing new instructional resources. The assessment function will be fully integrated with the instruction function, will provide authentic tasks to assess each student's 
performance, will give prompt feedback, and will support teachers in designing and developing student assessments (Reigeluth et al., 2008). In addition, PIES will have several built-in secondary functions, such as communication, general student data, school personnel information, and PIES administration (Reigeluth et al., 2008). PIES will play an important role in the coming Personalized Computing period by serving the trends identified above and performing the functions of an information-age educational system.

To conclude, although it is difficult to predict the future of educational computing, we can foresee some of the developments that are likely to characterize the next period of educational computing, and these developments should help us in our attempts to evolve toward an ideal use of technology to support education. Current trends indicate that we should start by changing the perception about computers in education. Instead of using them as a way to enhance teachercentered instruction, we should make use of computers as the major tool for teaching and learning in a learner-centered environment. Moreover, changes in the needs and nature of information-age students create different needs and expectations for educational technology. Looking at society's trends today will shed light on features of an information-age educational system. We see a great need for PIES since it supports personalized computing for an informationage educational system.

\section{References}

Alessi, S. M. \& Trollip, S. R. (1991). Computer-based instruction: Methods and development. Englewood Cliffs, NJ: Prentice-Hall.

American Heart Association. (2009). Aortic Aneurysm.Retrieved 1 January 2010 from http://www.americanheart.org/presenter.jhtml?identifier=4455

Amichai-Hamburger, Y. \& Hayat, Z. (2011). The impact of the Internet on the social lives of users: A representative sample from 13 countries. Computers in Human Behavior, 27, 585-589.

Archbald, D. A. \& Porter, C. P. (1994). Curriculum control and teachers' perceptions of autonomy and satisfaction. Educational Evaluation and Policy Analysis, 16(1), 21-39.

Banathy, B. H. (1991). Systems design of education: A journey to create the future. Englewood Cliffs, NJ: Educational Technology Publications.

Bichelmeyer, B. \& Molenda, M. (2006). Issues and trends in instructional technology: Gradual growth atop tectonic shifts. In M. Orey, V. J. McClendon \& R. M. Branch(Eds.),Educational media and technology yearbook: Volume 31, 2006 (pp. 3-32). Englewood, CO: Libraries Unlimited.

Brown, A. \& Green, T. D. (2007). Video podcasting in perspective: The history, technology, aesthetics, and instructional uses of a new medium. Journal of Educational Technology Systems, 36(1), 3-17.

Brown, A. \& Green, T. D. (2008). Issues and trends in instructional technology: Making the most of the mobility and ubiquity. In M. Orey, V. J. McClendon \& R. M. Branch (Eds.), Educational media andtechnology yearbook: Volume 33, 2008 (pp. 4-16). Englewood, CO: Libraries Unlimited. 
Charnitski, C. W. \& Harvey, F. A. (2007). Weblogs (blogs): Powerful new tools for more effective and efficient research on learning and teaching.In M. Orey, V. J. McClendon \& R. M. Branch (Eds.), Educational media andtechnology yearbook: Volume 32, 2007 (pp. 48-55). Westport, CT: Libraries Unlimited.

Christensen, C. M., Johnston, C., \& Horn, M. (2008). Disrupting class: How disruptive innovation will change the way the world learns. New York, NY: McGraw-Hill.

Cuban, L. (1986). Teachers and machines: The classroom use of technology since 1920. New York, NY: Teachers College Press.

Cuban, L. (2001). Oversold and underused: Computers in the classroom. Cambridge, MA: Harvard University Press.

Darling-Hammond, L. (1990). Achieving our goals: Superficial or structural reforms. Phi Delta Kappan, 72(4), 286-295.

Duffy, F. M., Rogerson, L. G., \&Blick, C. (2000). Redesigning America's schools: A systems approach to improvement. Norwood, MA: Christopher-Gordon Publishers.

Duffy, T. M. \& Cunningham, D. J. (1996). Constructivism: Implications for the design and delivery of instruction. In D. Jonassen (Ed.), Handbook of research for educational communications and technology (pp. 170-198). New York, NY: Simon \& Schuster Macmillan.

Earle, R. S. (2002). The integration of instructional technology into public education: Promises and challenges. ET Magazine, 42(1), 5-13.

Ebersbach, A., Glaser, M., \& Heigl, R. (2005).Wiki: Web collaboration. (A. Adelung, Trans.) Berlin, Germany: Springer-Verlag.

Frick, T. W. (1991).Restructuring education through technology. Bloomington, IN: Phi Delta Kappa Educational Foundation.

Fullan, M. (1993). Change forces: Probing the depth of educational reform. London ; New York: Falmer.

Fullan, M. (2003). Change forces with a vengeance. New York: Routledge.

Garrison, D. \& Cleveland-Innes, M. (2005). Facilitating cognitive presence in online learning: Interaction is not enough. American Journal of Distance Education, 19(3), 133-148.

Godwin-Jones, R. (2003). Blogs and wikis: Environments for on-line collaboration. Language Learning \& Technology, 7(2), 12-16.

Golden, F. (1985). Here come the microkids'. In T. Forester (Ed.), The information technology revolution (pp. 218-228). Oxford, UK: Blackwell.

Huffaker, D. (2005). The educated blogger: Using weblogs to promote literacy in the classroom. AACE Journal, 13(2), 91-98.

Jenlink, P., Reigeluth, C. M., Carr, A. A., \& Nelson, L. M. (1998). Guidelines for facilitating systemic change in school districts. Systems Research and Behavioural Science, 15(3), 217-233.

Jonassen, D. H. (1996).Computers in the classrooms: Mindtools for critical thinking. Englewood Cliffs, NJ: Prentice Hall. 
Jonassen, D. H., Peck, K. L., \& Wilson, B. G. (1999). Learning with technology: A constructivist perspective. Upper Saddle River, NJ: Prentice Hall.

LOGO Foundation. (2000). What is LOGO?. Retrieved from http://el.media.mit.edu/Logofoundation/logo/index.html

Merrill, M. D., Schneider, E. W, \& Fletcher, K. A. (1980). TICCIT. Englewood Cliffs, NJ: Educational Technology Publications.

Merrill, P. F., Hammons, K., Vincent, B. R., Reynolds, P. L., Christensen, L., \&Tolman, M. N. (1996). Computers in education. Boston, MA: Allyn and Bacon.

Molnar, A. R. (1997). Computers in education: A brief history. Technology Horizons in Education Journal, 24(11), 63-68.

Morrison, G. R., Lowther, D. L., \& DeMeulle, L. (1999). Integrating computer technology into the classroom. Upper Saddle River, NJ: Prentice Hall.

Mott, J. \& Wiley, D. (2009). Open for learning: The CMS and the open learning network. In Education - Technology and Social Media, 15(2). Retrieved from http://www.ineducation. $\mathrm{ca} /$ article/open-learning-cms-and-open-learning-network

Papert, S. (1999).Logo philosophy and implementation. Montreal, Canada: Logo Computer Systems.

Pea, R. (2000).The Jossey-Bass reader on technology and learning.San Francisco, CA: Jossey-Bass.

Prensky, M. (2001). Digital natives, digital immigrants.On the Horizon, 9(5), 1-6.

Rahmlow, H., Fratini R. C., \& Ghesquiere, J. R. (1980). PLATO. Englewood Cliffs, NJ: Educational Technology Publications.

Reigeluth, C. M. (1994). The imperative for systemic change. In C. M. Reigeluth \& R. J. Garfinkle (Eds.), Systemic change in education (pp. 3-11). Englewood Cliffs, NJ: Educational Technology Publications.

Reigeluth, C. M. (1995). Educational systems development and its relationship to ISD. In G. J. Anglin (Ed.), Instructional technology: Past, present, and future (2nd ed., pp. 84-93). Englewood, CO: Libraries Unlimited.

Reigeluth, C. M., Watson, W. R., Watson, S. L., Dutta, P., Chen, Z., \& Powell, N. D. P. (2008). Roles for technology in the information-age paradigm of education: Learning management systems. Educational Technology,48(6), 32-39.

Roschelle, J. (2003) Unlocking the learning value of wireless mobile devices. Journal Computer AssistedLearning, 19(3) 260-272.

Ross, S. M., Morrison, G. R., \&Lowther, D. L. (2010). Educational technology research past and present: Balancing rigor and relevance to impact school learning. Contemporary Educational Technology, 1(1), 17-35.

Saettler, P. (1990). The evolution of American educational technology. Englewood, CO: Libraries Unlimited. 
Scardamalia, M., Bereiter, C., \& Lamon, M. (1994). The CSILE project: Trying to bring the classroom into world 3. In K. McGilly (Ed.), Classroom lessons: Integrating cognitive theory \&classroom practice (pp. 201-228). Cambridge, MA: MIT Press.

Schmidt, M., Weinstein, T., Niemic, R., \& Walberg, H. (1986).Computer-assisted instruction with exceptional children. Journal of Special Education, 19(4), 493-501.

Schofield, J. (1995). Computers and classroom culture. Cambridge, UK: Cambridge University Press.

Sharma, P., Xie, Y., Hsieh, P., Hsieh, W., \&Yoo, S. (2008). Student learning outcomes in technologyenhanced constructivist learning environments: What does research show?.In M. Orey, V. J. McClendon \& R. M. Branch (Eds.), Educational media andtechnology yearbook: Volume 33, 2008 (pp. 77-90). Westport, CT: Libraries Unlimited.

Silberman, H. F. (1962). Application of research on programmed instruction to school systems. Ft. Belvoir, VA: Defense Technical Information Center.

Simonson, M. (2007). Course management systems.Quarterly Review of Distance Education, 8(1),7-9.

Singh, K. \& Dika, S. (2003). The educational effects of rural adolescents' social networks. Journal of Research in Rural Education, 18, 114-128.

Skinner, B. F. (1954). The science of learning and the art of teaching. Harvard Educational Review, 24(2), 86-97.

Stolurow, L. M. (1966). Socrates, a computer-based instructional system in theory and research. Ft. Belvoir, VA: Defense Technical Information Center.

Taylor, R. \& Chonacky, N. (1982). Computer in the school: Tutor, tool, tutee. American Journal of Physics,50, 91.

Toffler, A. (1980). The third wave. New York, NY: Bantam Books.

Tyack, D. \& Cuban, L. (1995). Tinkering toward Utopia. Cambridge, MA: Harvard University Press.

U.S. Congress, Office of Technology Assessment. (1988). Power on! New tools for teaching and learning (OTA-SET-379). Washington, DC: US Government Printing Office.

Venezky, R. \& Osin, L. (1991). The intelligent design of computer-assisted instruction. New York, NY: Longman.

Wells, J. \& Lewis, L. (2006). Internet access in U.S. public schools and classrooms: 1994-2005. Washington, DC: US Department of Education, National Center for Education Statistics.

Wikipedia. (2009). Web 2.0. Retrieved from http://en.wikipedia.org/wiki/Web_2.0

Woodward, J. \& Reith, H. (1997). A historical review of technology research in special education.Review of Educational Research, 67, 503-536.

Correspondence: Charles M. Reigeluth, Professor, Instructional Systems Technology, School of Education, Indiana University, Bloomington, IN 47405, United States. 